\title{
被災地の地域再生と生活支援 一社会福补学の立場から一
}

野口定久

3.11未曾有の東日本大震災と原発事故から、 1 年 6 カ月余りが経過した。しかし、いまだ優 先すべきは被災者の生活の立て直しであり、原 発事故の早期の収束である。いま日本では、社 会構造にかかわる三つの危機が襲っている。第 一は、主として先進国で共通に生じている超高 齢社会と少子化・人口減少社会という人口構造 の危機。第二は、デフレ不況、円高、株安によ る経済と財政と社会保障の危機。そして第三に は、高齢者介護・孤立化、ドメスティック・バ イオレンス、自殺、犯罪、ストレス等福祉問題 が多発する社会システムや家族・コミュニティ の持続可能性の危機である。そこに東日本大震 災と津波と原発事故が襲った。まさに、「四重 苦」である。本稿では、社会福祉学の立場から、 主として「居住福祉資源」・「地域福祉計画」・ 「ソーシャルワーク支援」の側面から被災地の 地域再生と被災者の生活支援の針路について 考察する。

\section{1. 被災地の復興と居住福祉}

被災地の復興・発展は、なにより人間の復興 であり発展でなければならない。それには、人々 が、生まれ育ち、生活の本拠を築いている土地・ コミュニティに住み続けられることが基本条 件となる。東日本大震災の被害の規模と深刻さ は、想像をはるかに上回るものであった。被災 直後から数力月間に被災現地に立つと、その惨
状の大きさに行く先々で出会う。近年に生じた 阪神淡路大地震や能登半島地震、中越地震で目 の当たりにしてきた被災直後の姿に何度も息 をのんだ。現在でも、復興住宅での孤独死など 痛ましい事故（阪神淡路大震災では、仮設住宅 が存続した 5 年間で誰にも看取られずに死亡し たまま放置される孤独死が 233 人に達した）が 相次いでいる。さらに、被桨地は世界同時不況 の波も押しよせ、震災と経済危機の二重の被害 を受けている。震災を契機に経済の地域格差、 貧困の拡大に拍車がかかりかねない。その意味 で、地震、災害時にこそ、その国の社会の矛盾、 問題点が顕著に現れる。過去の大震災後の復旧・ 復興の教訓に学んだ、復興のイノベーションが 問われている。また、被桨者や原発事故地域の 住民の居住権の問題である。被災地では、「暑 さ寒さが厳しい季節ほど孤独感を募らせるお 年寄りが多くなる」といわれている。自分の居 場所を見つけられなくて悩む人々が、自分の意 志を主張できる緩やかな空間づくりが、被災地 のまちの一角で続けられている。

各地で起こっている災害復興の当面の政策 目標は、まずは被災住民の生活の立て直しであ る。被災時の住宅政策としては、避難所が長期 化しないように住宅の確保が急務である。その 際、阪神淡路大震災の教訓としてコミュニティ を壊さない仮設住宅の建設が強調されてきた が、その教訓が活かされにくい状況が見受けら れる。また、東日本大震災の仮設住宅一棟当た 
りの価格が平均約 500 万円で、法基準の二倍に のぼることが分かった（夏の暑さ、冬の寒さ対 策に難がみられる)。避難所から仮設住宅へと いう一連の定型化された住宅施策に注文をつ けたい。高騰する仮設住宅の建設費用を直接、 被災者の常設住宅の建設費に回し、行政と地元 業者、地域住民の三者協働で、新たなコミュニ ティを創りなおすことを提案したい。第二に、 災害に強い地域社会と街づくりである。(1)地域 社会で高齢者・障害者等災害弱者を支える仕組 みづくり、(2)空き家や減反田、里山の保全、(3) 被災地は高齢化や少子化が進んだ地域が多く、 社会保障と税制の一体改革等ソフト面での災 害復興が急がれる。第三に、医療・福祉・介護 サービスの整備である。高齢者が多い地域に災 害支援の訓練を特別に受けた「災害支援ナース」 の派遣、介護福祉士や社会福祉士等専門職の派 遣も継続的に行うことが必要である。特に、在 宅や仮設住宅等に暮らしている高齢者の孤立 化を防ぐ手段として見守り活動の実施。在宅の 高齢者や障害者への通所介護サービス、訪問介 護サービスの増大。「生活に支障はないか」ニー ズの把握とともに、困りごとの相談や一緒に問 題解決にあたる支援活動なども必要である。第 四に、地域産業と雇用の創出である。1995年 の阪神淡路大震災時の建築物、交通基盤など 失われたストックの額は約 9.6 兆円であったが、 今回の被災額は約 20 兆円ともいわれている。 住宅や工場、道路、鉄道、橋、港湾等の投資規

\section{PROFILE}

野口定久

(のぐち さだひさ)

日本学術会議連携会員、日本福祉大 学社会福祉学部教授、同大学院委員 長、日本社会福祉学会副会長、日本 社会福祉系学会連合会長・東日本大 震災対応委員会委員長

専門: 地域福祉. 社会福祉計画. 居 住福祉

模は大きな需要を喚起し、ケインズ型公共投資 政策の実施によって成長率と当面の雇用が拡 大するであろう。

\section{2. 被災地の再生と地域福祉計画}

震災後のハード面の復興街づくり計画が各 地で進んでいるが、ソフト面を重視した地域再 生（地域福祉）計画は、いまだ取り組みが遅れ ている。被災者の生活再建と復興プランに関 する被災者アンケート（2011年5月実施、岩手 日報。あなたが市町村長ならどちらの考えを尊 重しますか）の結果によると、「被災者の生活 再建を尊重する」が34.5\%、「国と県とつくる 復興プランを重視する」が65.5\%であった。高 齢化や過疎化の地方の現状は、震災以前から厳 しかった。復興プランの成否は、地方が抱える 構造問題への答えを盛り込めるかどうかにか かっている。被災者の生活再建を尊重した、国・ 県・自治体レベルごとの復興プランの作成が急 がれる。

被災者の生活再建と地域の再生・復興プラン の波及効果を三つ挙げておく。第一は、家族機 
能の低下や地域共同性の衰退によってもたら される個別の福祉問題に社会福祉専門職とし て実践的に介入し、さらに地区ごとのソーシャ ル・キャピタルの蓄積や地域居住資源（ストッ ク）の活用によって、縮小する家族・地域社会 の親密圈を補強することになるであろう。第二 は、ローカル・ガバナンスによる豊かな公共圈 （行政と住民と事業所の協働による社会的企業 やコミュニティ・ビジネス等) の形成が可能に なる。第三は、被災地に広がる格差社会の改善 には、それぞれの地域（メゾ）レベルにセーフ ティネット（社会保険・社会福祉・公的扶助） を張り替える作業を通して、地域住民の生活保 障を確立すること等である。

\section{3. 災害とソーシャルワーク}

被災者や被災地の間に支援の格差が現われ はじめている。従来からの日本社会が抱える少 子化・人口減少と超高齢化と過疎化に直面しな がら医療や福祉行政、生活機能などが拡散して いた地方のもろさの表れでもある。地域社会で 高齢者や子どもたち等の被災者の生命や生活 を支える仕組みを早くつくらなければならな い。東日本大震災発生時から復興に向けてのプ ロセスが地域よって大きく異なり、時間差も生 じているが、概ね、次のステップで進行するこ とになる。被災時 $\rightarrow$ 避難所（福祉避難所） $\rightarrow$ 復 旧 (生活再建) $\rightarrow$ 復興（新たな地域の創生）の

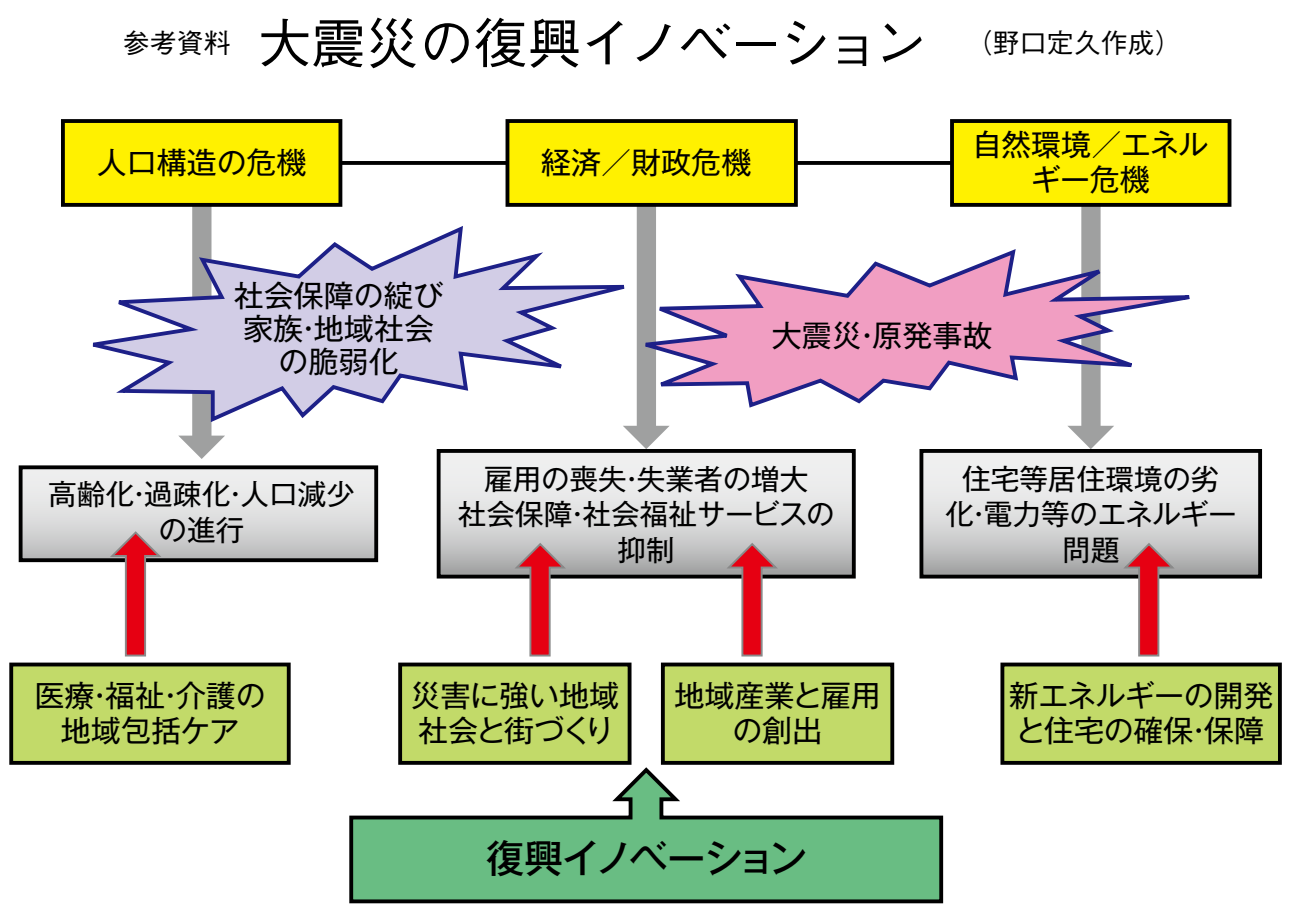


経過を辿っている。ソーシャルワーク支援活動 のプロセスは、災害発生時の対処や避難所、仮 設住宅、在宅での生活や心身の生活問題の把握 $\rightarrow$ 被支援者の居住環境の分析 $\rightarrow$ 被支援者の居 場所・ステージごとの支援活動の展開 $\rightarrow$ 福祉版 DMATの導入 $\rightarrow$ 地域包括支援システムの構築 $\rightarrow$ 地域福祉計画・復興プランを通しての政策提 起を、被支援者からヒアリング、時間的経過の 中で事例検討を積み重ねながら、専門職間・支 援団体間の継続的支援の全体像を共有化する必 要がある。

被災により、被災者は避難所生活（要介護高 齢者や障害者は福祉避難所）から始まり、仮 設住宅および復興住宅への移動を経て、居住地 での生活の再建とまちづくりへと展開してい く。震災での最も初期段階は超急性期や急性 期の患者に対して医療が対応することになる。 これについては、DMAT（Disaster Medical Assistance Team）が相当うまく機能したとの 報告がある。

この間、様々の職能団体やNPO組織、福祉 系大学及び福祉系学会連合などがそれぞれの 団体の特徴を生かした復旧・復興に向けての支 援活動を行っているが、いまだ個々の活動範囲 内に留まっている。今後は、それぞれの団体 が補完・協力し合いながら、被災者・被災地・ 原発污染地域の生活再建や心身のソーシャル ワークにおいて、それぞれの団体が保有する情 報や方法を共有化し、復旧・復興に向けて大き な責任を担っていく必要があるのではないか
と考える。被災者の生活立て直し、被災地の復 興に向けて社会福祉、特にソーシャルワークと 地域福祉計画に大きな期待が寄せられている。 その意味では、これからが社会福祉学、ソーシャ ルワーク支援の「出番」である。 